\title{
Research Paper \\ The Mediating Role of Fear of Negative Evaluation in the Relationship between Resilience and Academic Buoyancy with Loneliness in Siblings of Children with Neurodevelopmental Disorders
}

\author{
Soheila Yosefi ${ }^{1}$, Somayeh Keshavarz ${ }^{* 2}$, Alireza Kakavand ${ }^{3}$ \\ 1. M.A. in Psychology, Faculty of Social Sciences, Imam Khomeini International University, Qazvin, Iran
}

2. Assistant Professor, Department of Psychology, Faculty of Social Sciences, Imam Khomeini International University, Qazvin, Iran

3. Associate Professor, Department of Psychology, Faculty of Social Sciences, Imam Khomeini International University, Qazvin, Iran

Citation: Yosefi S, Keshavarz S, Kakavand A. The mediating role of fear of negative evaluation in the relationship between resilience and academic buoyancy with loneliness in siblings of children with neurodevelopmental disorders. Quarterly Journal of Child Mental Health. 2020; 7(3): 67-79.

\section{http://dx.doi.org/10.52547/jcmh.7.3.7}

\section{A R T I C L E I N F O}

Keywords:

Loneliness, neurodevelopmental disorders, resiliency, fear of negative evaluation, academic buoyancy

Received: 10 Jun 2020 Accepted: 18 Sep 2020 Available: 13 Dec 2020

\section{A B S T R A C T}

Background and Purpose: Neurodevelopmental disorders are a group of disorders that begin during the developmental period and before a child enters school and lead to impairment in individual, social, academic and professional functioning. The presence of a child with a disability in the family causes problems and tensions in the relationships between family members and the normal routin of their daily lives. The aim of this study was to investigate the mediating role of fear of negative evaluation in the relationship between resilience and academic buoyancy with loneliness in siblings of children with neurodevelopmental disorders.

Method: For this purpose, in a descriptive-correlational research project, among siblings of children with neurodevelopmental disorders living in Tehran and Karaj in 2019, 200 subjects aged 9 to 18 years were selected by convenience sampling method. The research instruments included the Child and Adolescent Resiliency Questionnaire (Ungar \& Linberg, 2009), Academic Buoyancy (Dehghanizadeh \& Hossein Chari, 2012), Feeling Lonely (Ashroohkemar, 2010), Fear of Negative Evaluation (Larry, 1983). Data were analyzed using path analysis modeling.

Results: The results showed that resilience and academic buoyancy had a significant negative effect; and fear of negative evaluation had a significant positive effect on loneliness $(\mathrm{p}<0.01)$. Also, the indirect relationship between resilience and academic buoyancy with loneliness in siblings of children with neurodevelopmental disorders is confirmed by the mediation of fear of negative evaluation $(\mathrm{p}<0.05)$.

Conclusion: In developing psychological interventions to improve loneliness in children, special attention should be paid to resilience and academic buoyancy and the mediating role of fear of negative evaluation. The presence of a child with a neurodevelopmental disorder in the family will have a profound effect on other family members, and environmental conditions such as family and community environment, emotional support of parents and friends, accessibility of facilities, and social and financial support can have significant effects on family functioning.

\footnotetext{
* Corresponding author: Somayeh Keshavarz, Assistant Professor, Department of Psychology, Faculty of Social Sciences, Imam Khomeini International University, Qazvin, Iran.

E-mail addresses: S.keshavarz@soc.ikiu.ac.ir
} 


\section{نقش واسطهاى ترس از ارزيابى منفى در رابطه بين تابآورى و سرزندگى تحصيلى با احساس تنهايى در همشيرهاى كود كان با اختلال هاى عصبى -تحولى دورى}

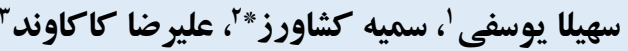

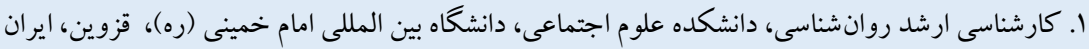

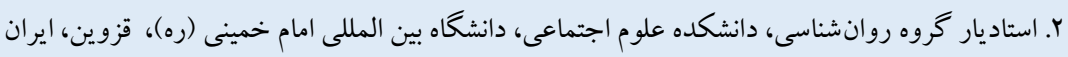

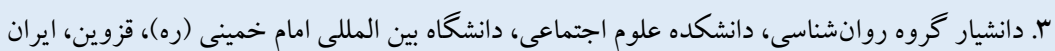

\section{جكيله}

زمينه و هدف: اختلالهاى عصبى-تحولى به كروهى از اختلالات كفته مىشود كه در دوره تحول و ييش از ورود كودكك به مدرسه شروع مى شوندو به آسيب در كار كرد فردى، اجتماعى، تحصيلى و حرفهاى، منجر مىشوند. حضور يكك كودك با ناتوانى در خانو اده، باعث ايجاد

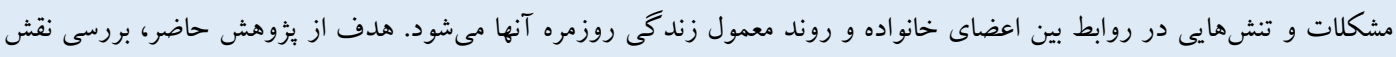
واسطهاى ترس از ارزيابى منفى بر رابطه بين تابَآورى و سرزندگى تحصيلى با احساس تنهايى در همشيرهاى كود كان با اختلالات عصبى تحولى است. روش: بدين منظور در يك طرح يزوهشى توصيفى- همبستگى، از ميان كود كان داراى همشير با اختلال عصبى- تحولى ساكن شهرهاى

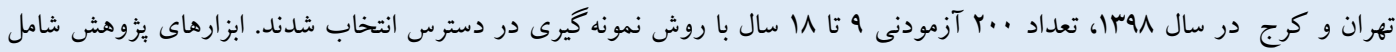

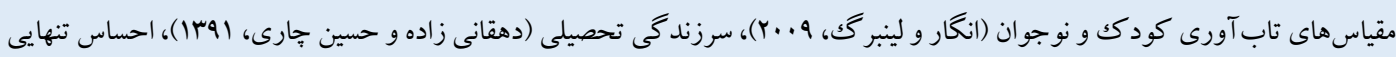

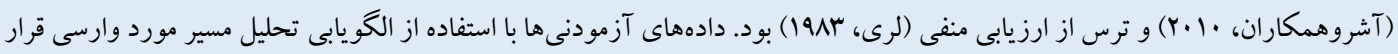

كرفتند. يافتها: نتايج نشان داد تاب آورى و سرزندگى تحصيلى، اثر منفى معنادار؛ و ترس از ارزيابى منفى تأثير مثبت معنادار بر احساس تنهايى

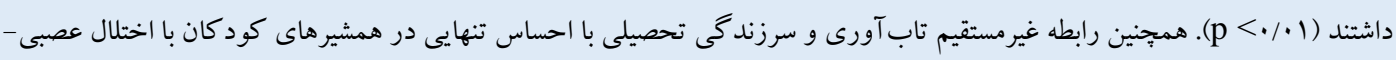

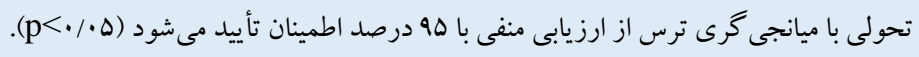

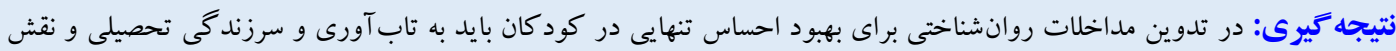

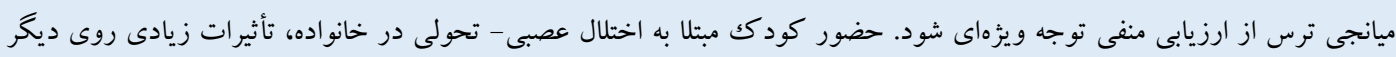

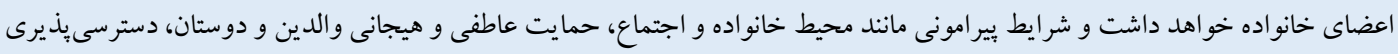

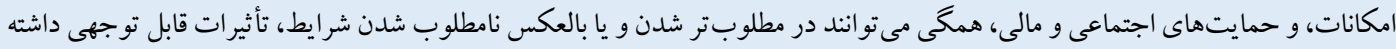

مشخصات مقاله

كليدوازهها:

احساس تنهايى،

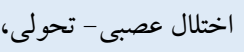

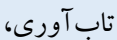
ترس از ارزيابى منفى، سرزندگى تحصيلى نرس

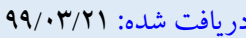

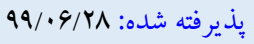

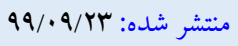

* نويسنده مسئول: سميه كشاورز، استاديار گرروه روانشناسى، دانشكده علوم اجتماعى، دانشكاه بين المللى امام خمينى (ره)، قزوين، ايران.

رايانامه: S.keshavarz@ soc.ikiu.ac.ir

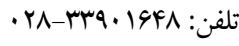


(ه)؛ اما گاهى اضطراب اجتماعى \عاملى براى دورى از روابط اجتماعى

مقلdo

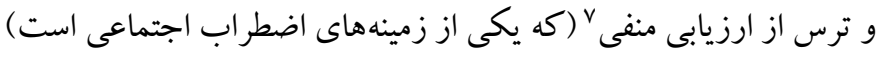

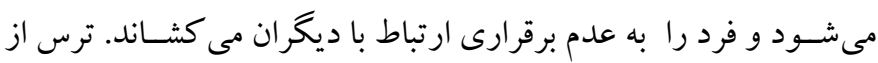
ارزيابى منفى باعث مى شود كه روابط اجتماعى فرد تحت تأثير قرار گيرد و با توجه به شرايط ويزهاى كه حضور يك كود كك بيمار در خانو اده مهيا مى كند، خصـيصــه ترس از ارزيابى منفى و مورد قضــاوت و تمســر

اطر افيان واقع شدن در اين كود كان، بسيار مشهود است (ه).

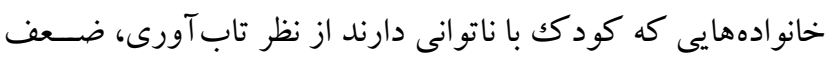

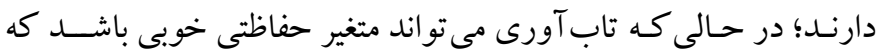
مشـكلات روانشـناختى حضـور كودك اسـثنايى را در اعضاى خانو اده

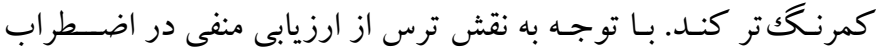

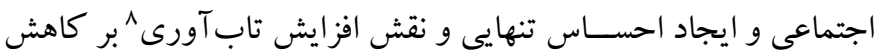

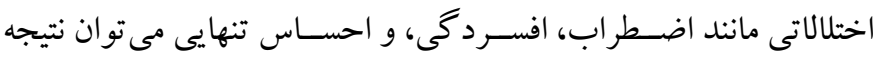
كرفت كه آموزش تابآورى موجب كاهش احسـاس تنهايى در افرادى

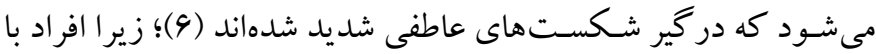
تاب آورى بالا، سـازش يافتكى بيشـتر و روحيه مشـار كت جويى بالايى از خود بروز مىدهند و در نتيجه، كمتر احسـاس تنهايى مى كنند. همجِنين

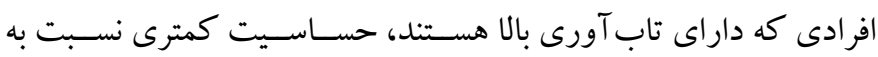

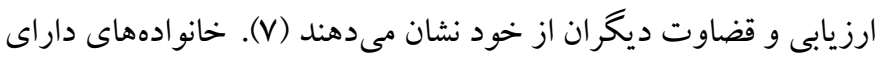
فرزند با ناتوانى، سطح تنيدگى بالاترى را به طور روزانه دريافت مى كنند.

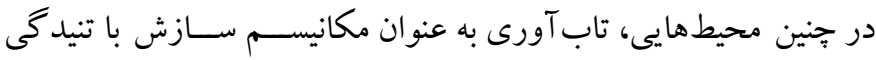

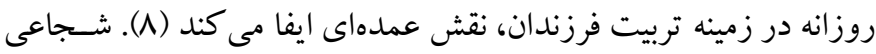

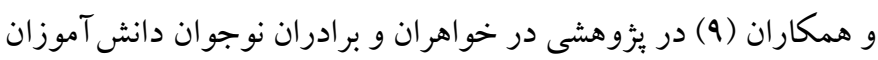

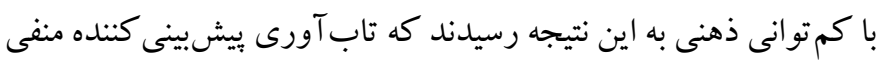
و معنادار نشـانهاى اختلال هاى جسـمى، اضطر ابى، كار كرد اجتماعى، و

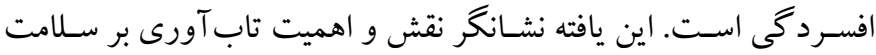
روانى خواهر ان و بر ادران دانش آموزان با كم توانى ذهنى اسـت. همجِنين

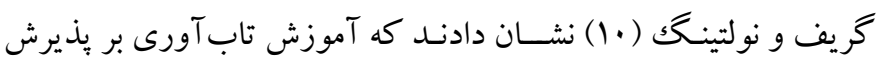
كودك و رابطه اعضاى خانو اده با هم، مؤثر است و كود كانى كه در اين

5. Loneliness

6. Social Anxity

7. Fear of negative evaluation

8. Resiliency
تولـد هر كودكى تـأثير زيـادى بر يويـايى خانو اده ايفا مى كند. والدين و

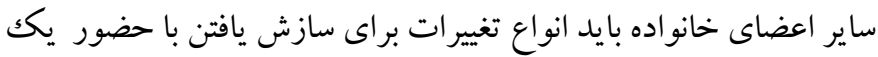

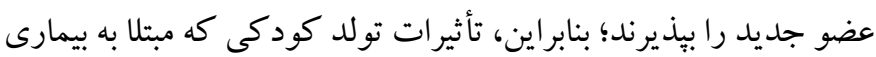
است بر خانو اده، دو برابر مى شود. حضور كودكك بيمار مى تواند خانو اده را در معرض خطر فزاينده تنيدگى' قرار دهد (1).

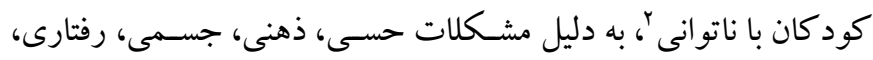

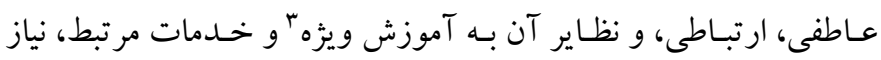

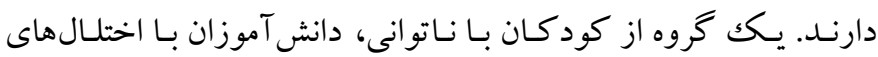

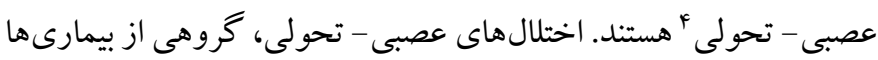

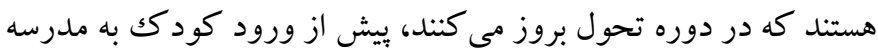
شـروع مىشوند، با نقايص تحولى مشخص مى شوند، و سبب تخريب در كار كرد شخصى، اجتماعى، تحصيلى، و يا شغلى مى شوند (Y).

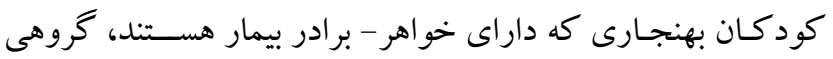
آسيب بذير در نظر كرفته مى شـوند كه در معرض خطر فز فز اينده مشكلات

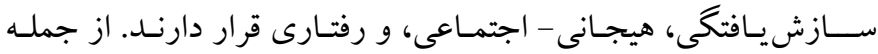

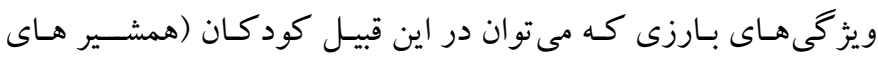

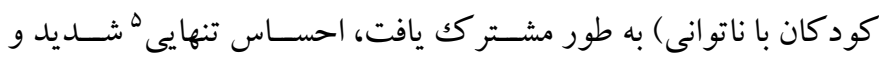
دورى از جمع دوسـتان اسـت. احسـاس تنهايى، به نوعى به كاسـتى در روابط انسـانى و تعاملات بين فردى ناكافى اشـاره داردكه ممكن اسـت از كيفيت نامطلوب در اين روابط ناشسى شــود (r). احساس تنهايى تجربه

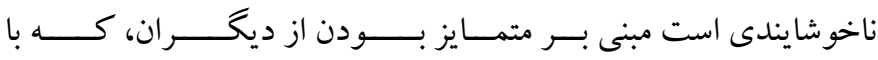

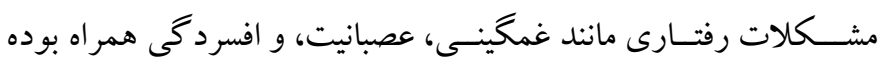

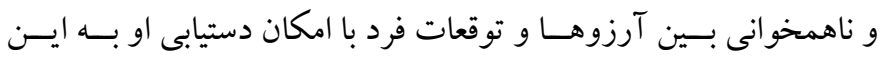

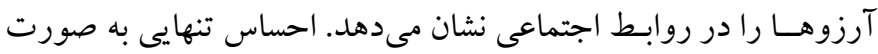

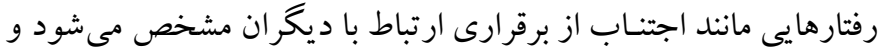

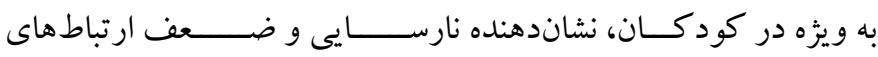
درونفـــــى و بين فردى است (F). مشــكلات هيجانى و روانشناختى بسيارى در كودكان و نوجوانـان داراى احساس تنهايى مشـاهده مى شود

1. Stress

2. Children with disability

3. Special Education

4. Neurodevelopmental disorders 
كود كك بيمار در خانو اده، فرصت هايى را براى تحول و بختخى، همدلى

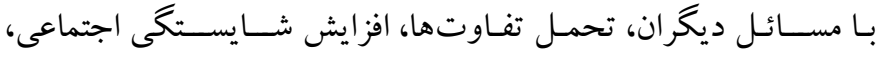
مسئوليت بذيرى و استقلال همشير ها فر اهم سازد (IV). در مجموع از آنجا كه تولد يكك كودكك بيمار به عنوان يكك بحران

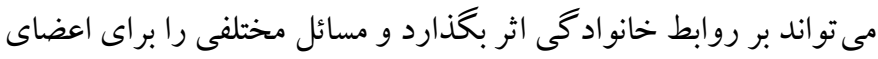
خانو اده به همراه داشـته باشــ، از اين جهت بررسى سلامت روان و روابط

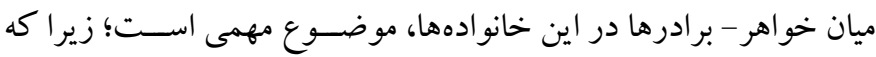

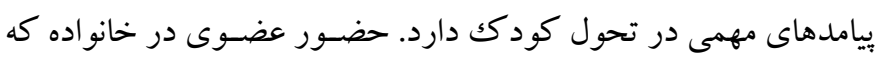

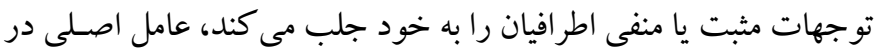
ايجاد خصـيصـه ترس از ارزيابى منفى در همشـير هاى سـالم اين گُونه

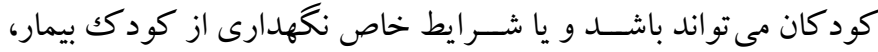

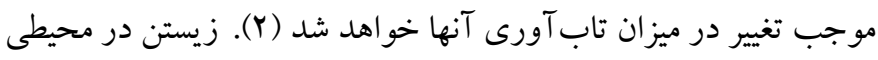
مشـتر كك با كود كك مبتلا به اختلال عصسبى -تحولى مى تو اند اند احتمال بروز

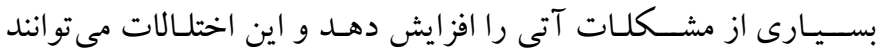
زمينهسـاز افزايش آسـيبذيذيرى در خواهر و برادران اين كود كان شـود

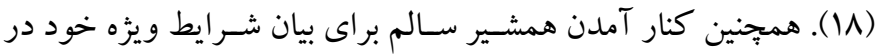
خانه و قدرت بيان آن در ميان هم كلاسى ها در مدرسه و تو انايى برقرارى

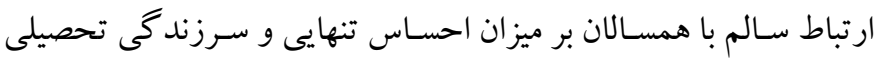

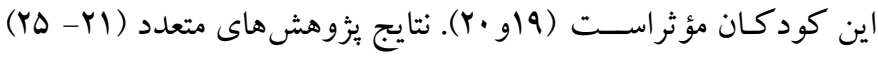
مؤيد اين موضوع است. با توجه به اهميت بهزيسـتى اعضساى خانو اده داراى فرزند ناتوان و

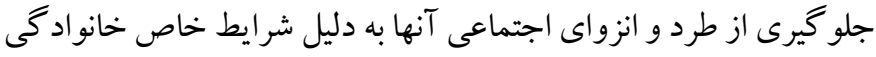

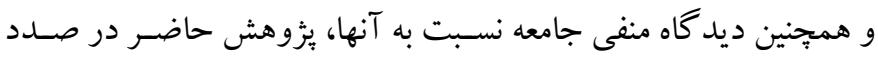

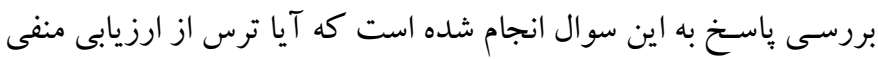

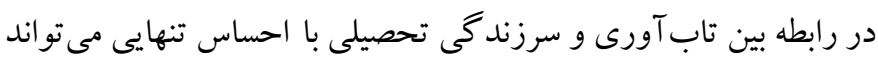
به عنوان متغير واسطهاى عمل كند؟

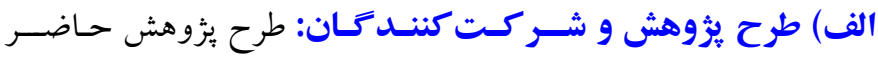

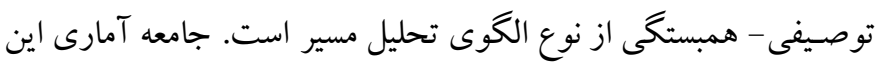
يُزوهش شامل تمامى كو كان 9 تا ل1 سال ساكن شهرهاى تهر ان و كرج

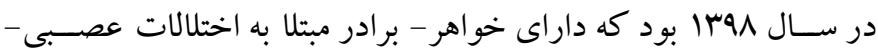

خـانوادههـا آموزش تـاب آورى ديــه بودنـل، كمتر از ديخر كودكان در

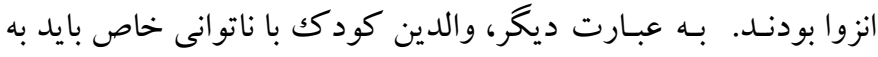

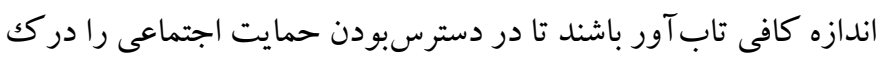

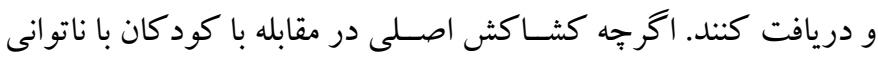

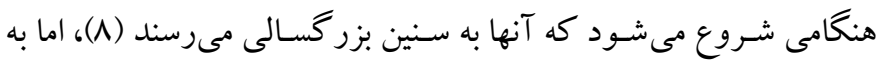

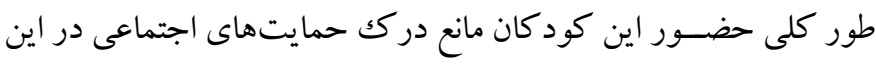
قبيل خانو ادهها نمى شود (11).

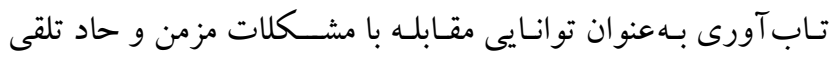

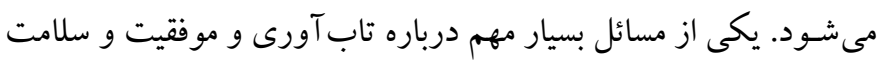

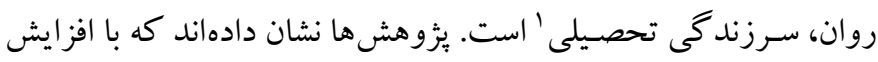
تاب آورى، موفقيت در مواجهه با شـــايط نامطلوب در طى تحصـيل و

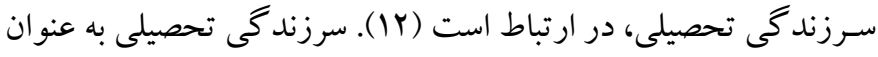

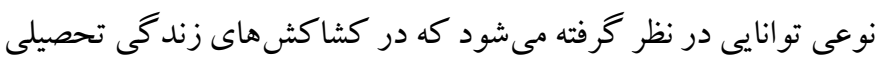

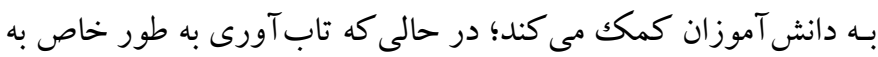

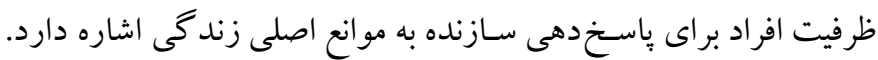

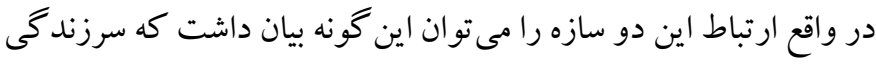

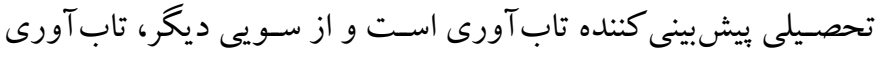

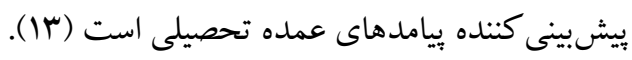
تعامل افراد بيمار با همشيرهايشان، موضوع مهم و قابل توجهى است.

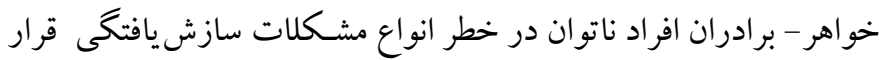

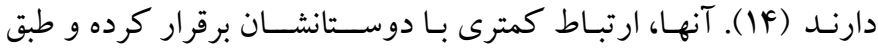
درجهبندى والدين و معلمان، مشكلات رفتارى و علائم اضطر ابى بيشترى بـ برى را تجربه مى كنند (ها و 19). در واقع حضور يكك كود وك بيمار يا ناتوان

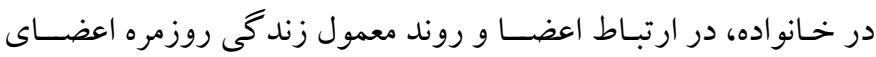
خانو اده، سـبب تغيير اتى مى شود و مى تواند به آشفتكى در نظام خانو اده،

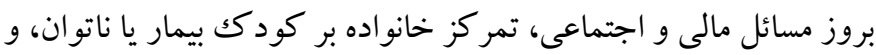
متعاقب آن كاهش فرصتهاى با هم بودن و تفريح و تعاملات يدر و مادر

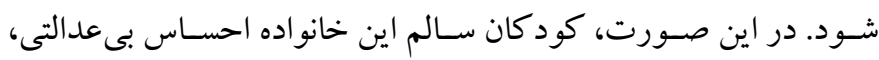
كامنايافتكى، حسـادت، و رنجش كرده و و اين احســاسـات منفى آنها به ونه

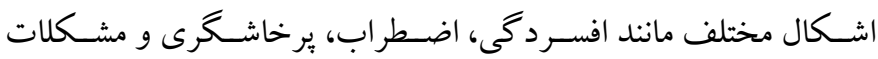

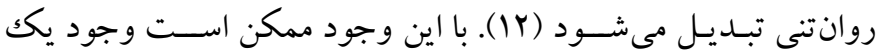


تمام گو يهها را جمع كرده و نمره حاصسل راوارد نرمافزار مى كنيم. حد

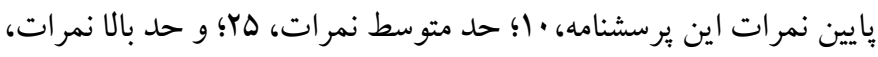

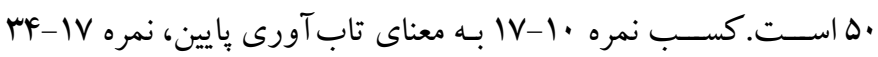
تاب آورى متوسط، و بالاتر از مY نشان دهنده تاب آورى بالا است (YV).

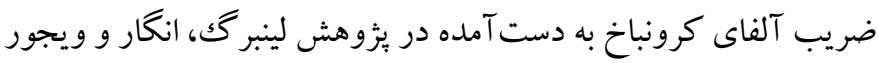

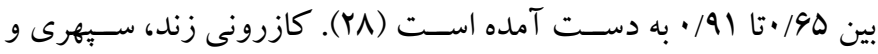

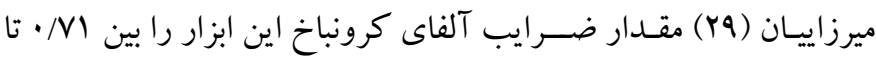

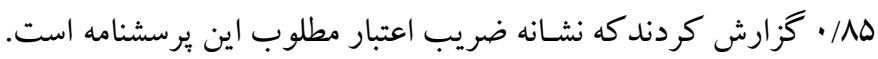

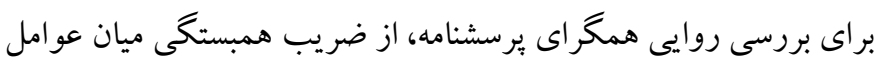

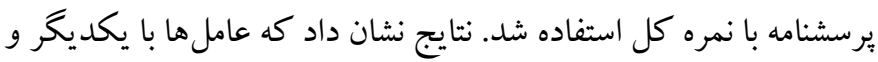

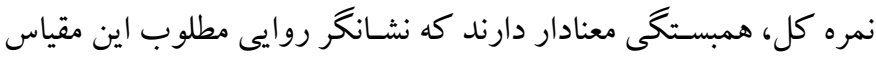
اسـت. به طور كلى نتايج مربوط به وارسى شـاخص هاى دماى روانسنجى اين

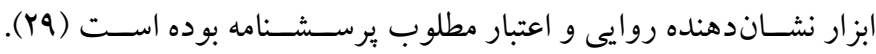
همســانى درونى اين مقياس بر اسـاس نمونه يزوهش حاضـر نيز به روش

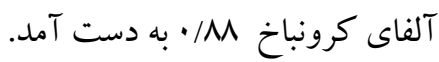

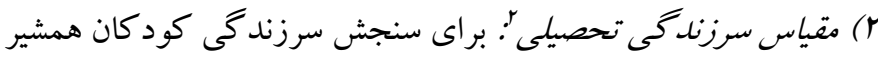

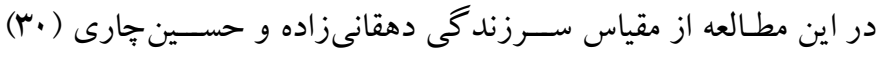

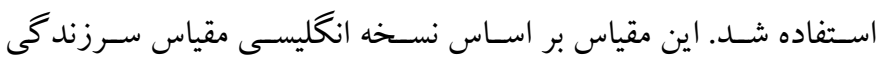

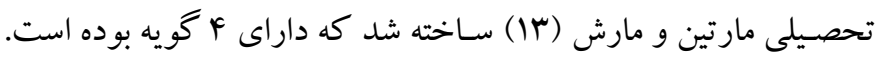
مقيـاس مارتين و مارش از جنبه هاى همسـانى درونى و باز آزمايى، معتبر

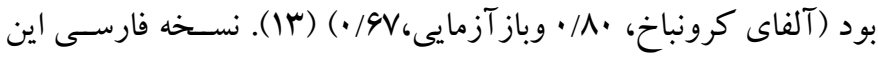

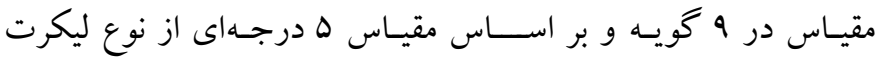

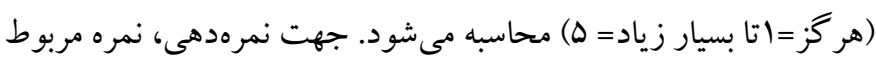

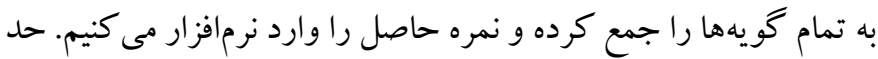

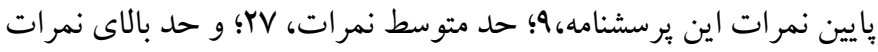

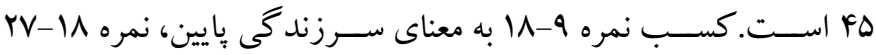

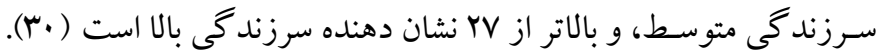

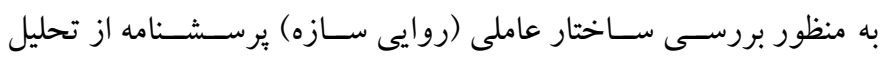

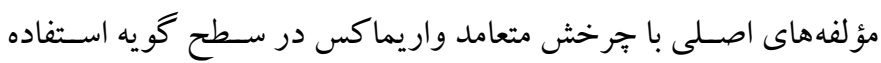

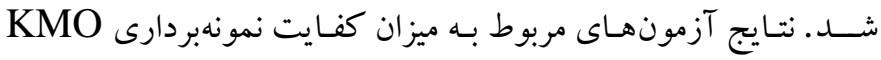

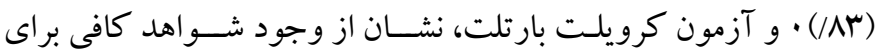

تحولى (مانند اوتيسـم، نشانكان داون، آسب بينايى و شنوايى، و اختلالات

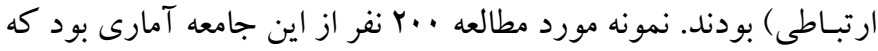

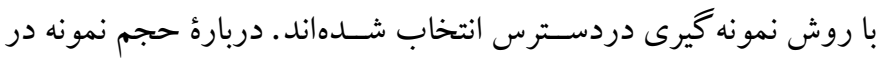

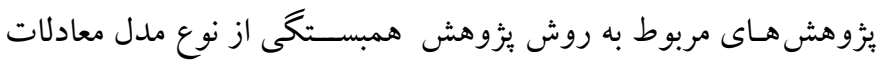

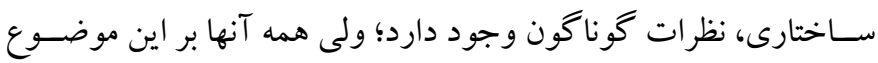
توافق دارند كه مدل معادلات ساختارى، شبيه تحليل عامل از فنون آمارى

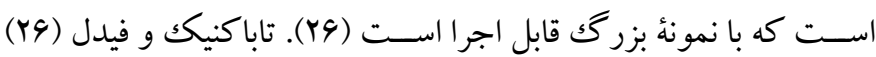

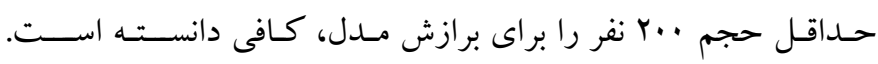

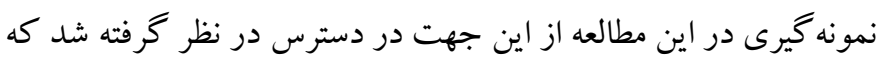
به خاطر مشـكلات اجر ايى، انتخاب افر اد نمونهب هـ صـورت تصــادفى

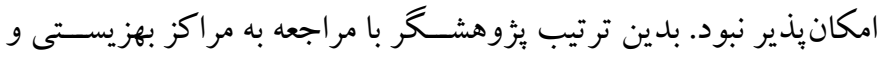

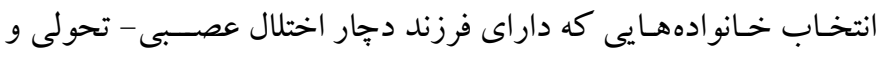

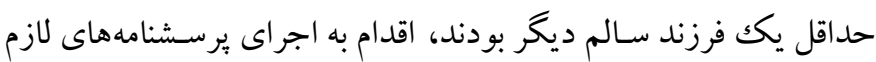

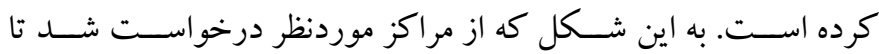
يرسشــامه مذكور را به دسـت خانو اده فرد با ناتوانى برسانند و از همشير

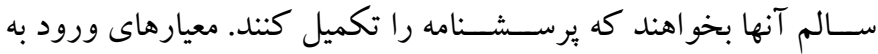
يُزوهش شـامل رضـايت كامل آزمودنىها جهت ورود به ئزوهش، دامنه

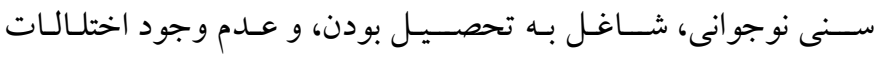
روانشـناختى در برادر و خواهر كود كان ناتوان بود كه اين موضسوع در

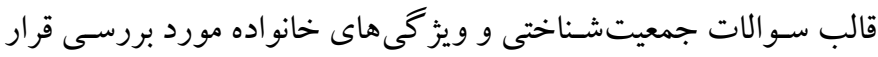

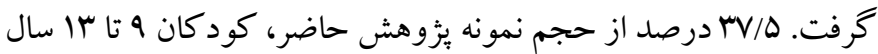

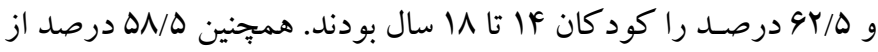
حجم نمونه، يسر و أl أ درصد نيز دختر بودند. ابزار

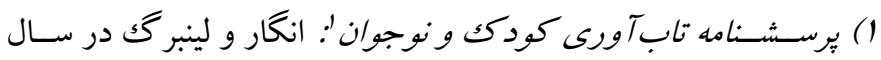

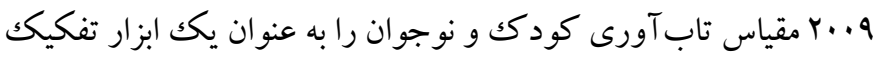
براى كثــف منـابع (فردى، ارتباطى، و بافتى) تاب آورى طر احى كردند

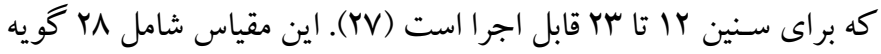

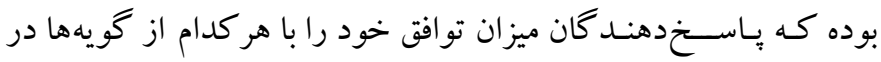

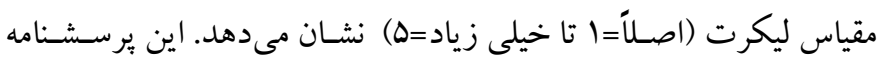

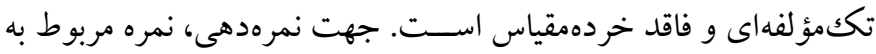


مؤلفههاى اصلى انجام دادن كه نتايج به دست آمده مطلوب بوده است.

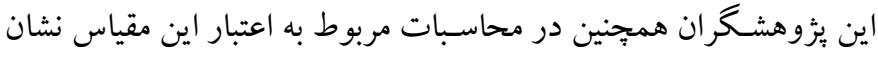

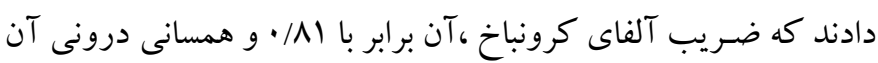

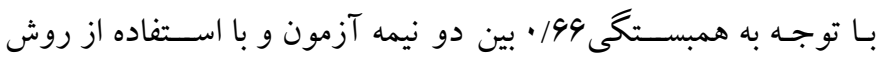
تصنيف در سطح قابل قبولى است. لازم به ذكر است كه همسانى درونى

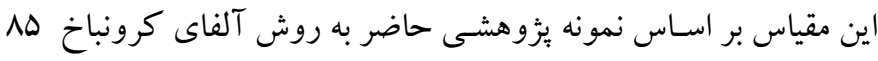

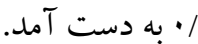

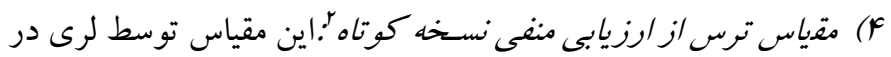

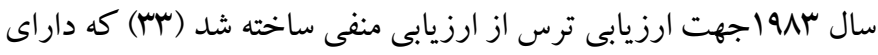

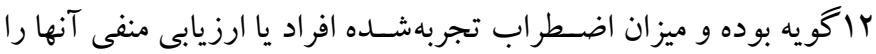

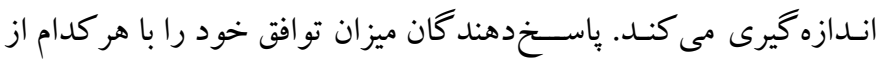

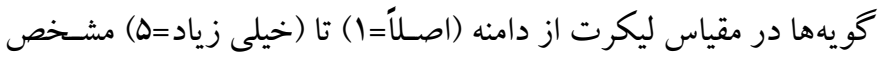

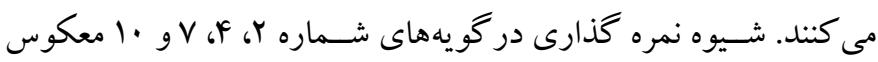
بوده و به صسورت (اصـلا=ه) تا (خيلى زياد=|) محاسـبه مىشـود. جهت

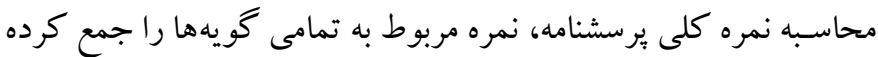

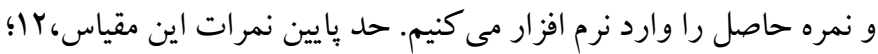

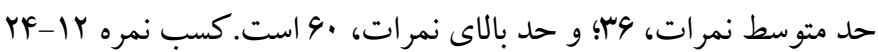
به معناى ترس از ارزيابى بايين، نمره بF-YY ترس از ارزيابى متوسط، و

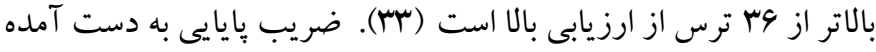

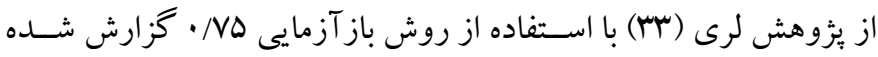

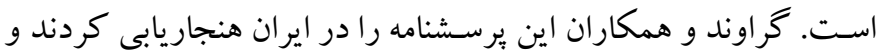

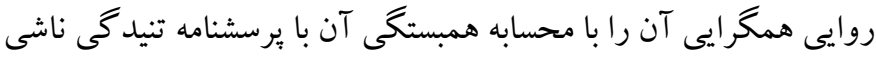

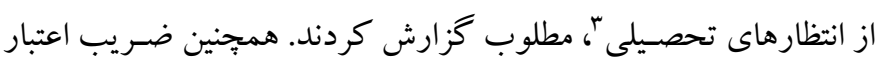

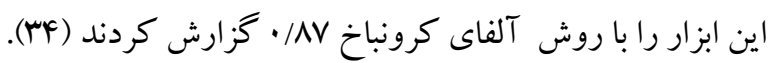
روش اجرا

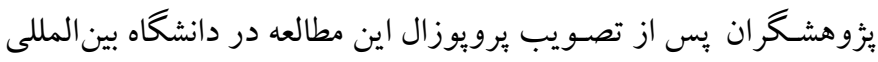
قزوين و با كسب مجوزهاى للازم علمى و اجرايى به اداره بهزيستى شهر

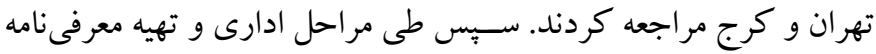
از اداره بهزيستى به مراكز توانبخشى كود كان سطح شهر تهران (مركز

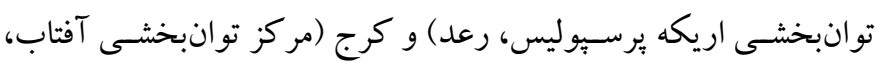

انجـام تحليـل عـامـل بود. ضــريب آلفاى كرونباخ نيز •^/، • و ضــريب

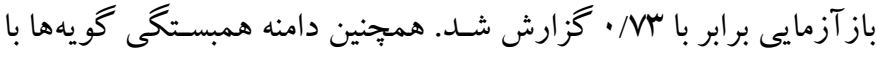

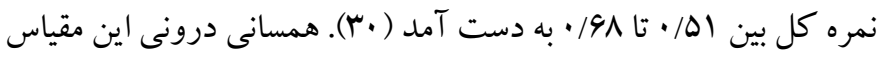

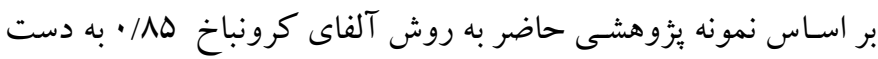

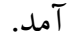

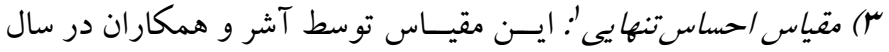
19AF

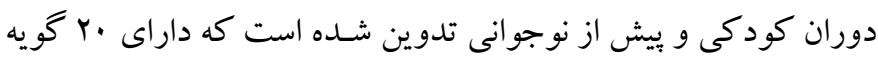

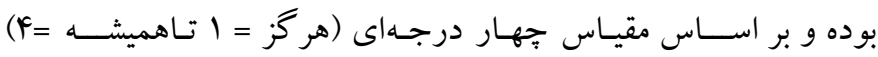

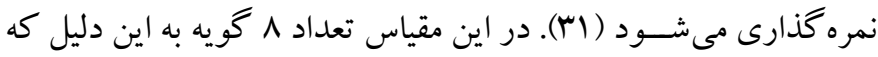

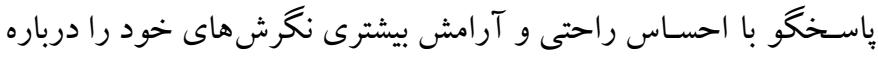

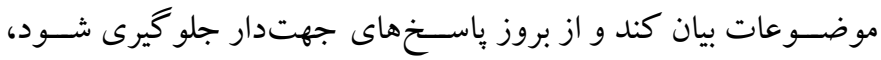

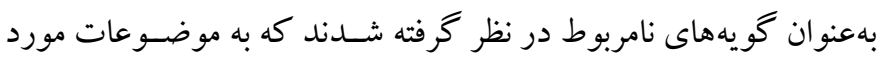
علاقه كود كان مرتبط هستند و در محاسبه امتيازات مقياس، در نظر خرفته

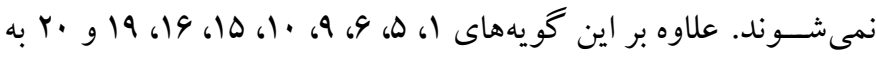

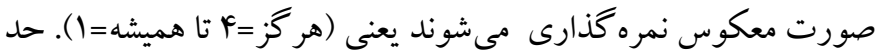

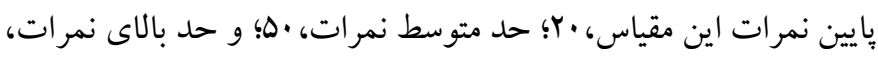

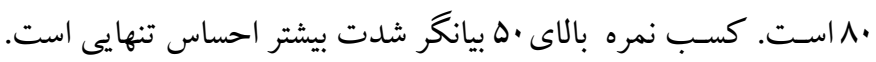

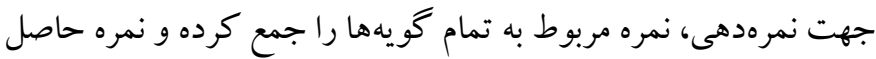

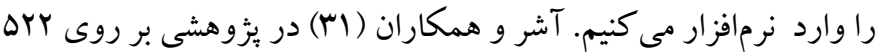
كود كك بهنجار r ا ساله نشان دادندكه ضريب بايايى اين آزمون با استفاده

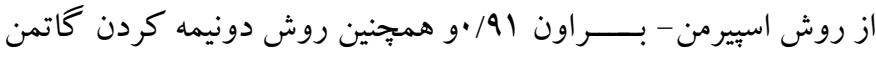

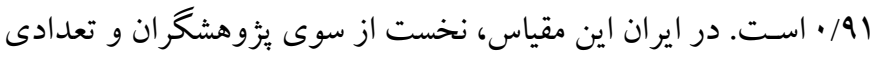
از اسـتادان مجرب روانشـناسى به فارسى ترجمه شده و سبس توسط دو

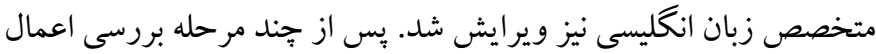
تغييرات و اصلاحات، روايى محتوايى اين برسشنامه به كمك جِند تن از

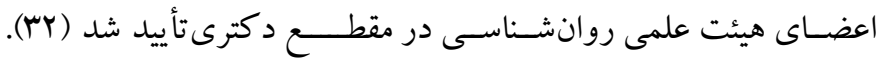

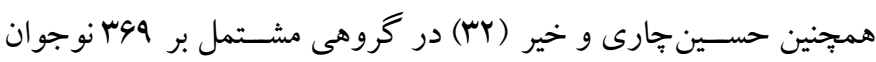
نشـان دادند اين مقياس از ثبات درونى مناسبى برخوردار اسـت و جهت

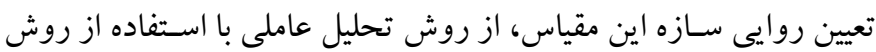


يافتهها

در جـدول ا شــاخص هاى توصـيفى متغيرها شــامل ميانخين، انحر اف

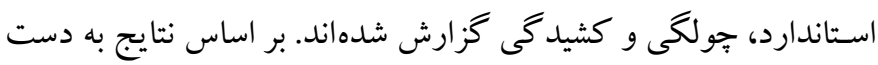

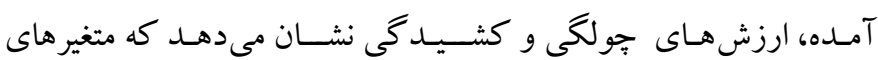
يثزوهش توزيع نرمال دارند.

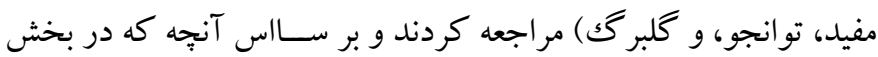

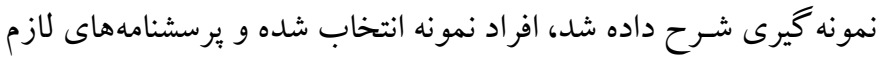
روى آنها اجرا شد. براى اجر ایى اين مطالعه تمامى ملاحظات اخلاقى مانند

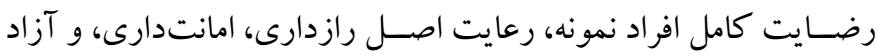
بودن براى انصـراف از شـركت در ئزوهش در هر مرحله از آن، به طور

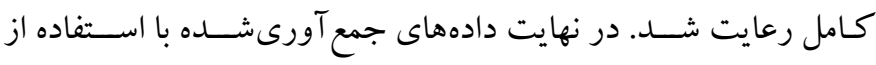
الكويابى تحليل مسير مورد آزمون قرار گرفت.

جدول 1: يافتهاى توصيفى مقياسهاى يزوهش

\begin{tabular}{|c|c|c|c|c|c|}
\hline كشيدكى & جولَى & انحراف استاندارد & ميانكين & تعداد & شاخص آمارى \\
\hline.$- / 99$ &.$- / .91$ & $10 / \Delta F$ & $1 .+/ \Delta r$ & $r .$. & تاب آورى \\
\hline -•/rar &.$/ \% \uparrow \wedge$ & $v / W$ & rN/91 & r.. & سرزندگى تحصيلى \\
\hline$-\cdot N I V$ &.$- / \cdot r \Delta$ & r/or & $r N / T F$ & $r \cdot$. & ترس از ارزيابى منفى \\
\hline$\cdot /$ ATV &.$/ r \Delta$ & $9 N T$ & $r q / .1$ & $r .$. & احساس تنهايى \\
\hline
\end{tabular}

مارديا براى دادههاى يُووهش حاضر برابر با T/ TV به دست آمد كه نشان

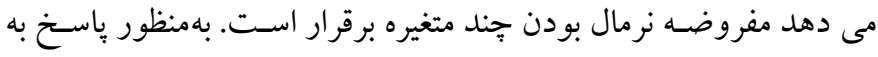

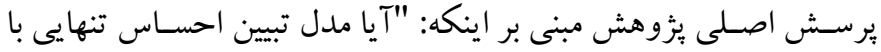

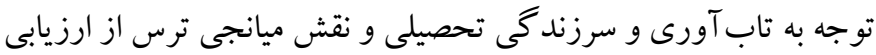

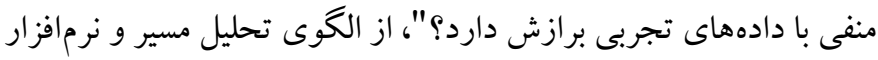

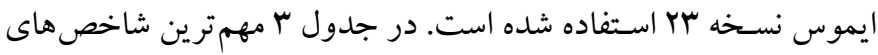

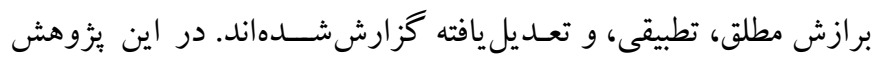
شـاخص نيكويى برازش (GFI)، شـاخص نيكويى برازش تعديل يافته (AGFI)، و ريشه ميانگين مربعات باقيمانده استاندارد شده (SRMR) به عنوان شـاخصهاى برازش مطلق، شـاخص برازش تطبيقى (CFI)،

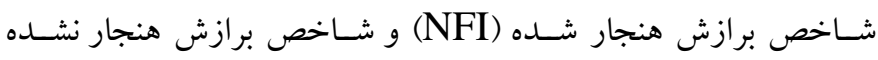
(NNFI) ايجاز (PNFI) و مجذور ميانخين مربعات خطاى تقريب (RMSEA) به عنوان شاخصهاى برازش مقتصد در نظر گرفته شدند.
در جدول Y ماتريس همبســـى متغيرهاى بثزوهش ارائه شــده اسـت. با

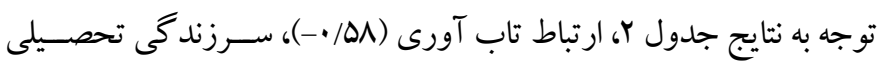

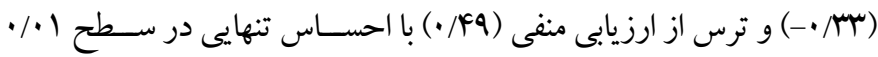
معنادار است.

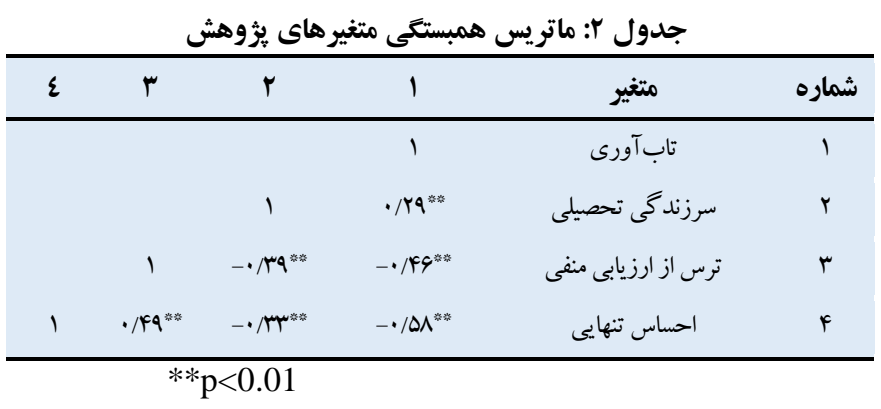

براى وارسـى نرمال بودن توزيع جند متغيرى در نرم افزار ايموس از

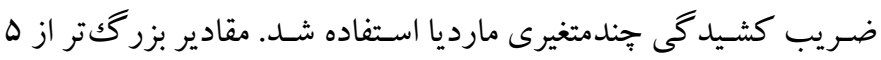
براى اين ضريب، نشان دهنده توزيع غيرنرمال دادهها است. مقدار ضريب 
جدول rا: شاخصهاى نيكويى برازش التوى آزمون شده بزوهش

\begin{tabular}{|c|c|c|c|}
\hline \multicolumn{4}{|c|}{ شاخصهاى برازش مطلق } \\
\hline SRMR & AGFI & GFI & شاخص \\
\hline.$/ . r$ & . /9r &.$/ 94$ & مقدار بهدست آمده \\
\hline كمتر از هـ/• ـ & 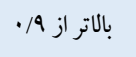 & 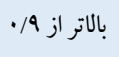 & حد قابل يذيرش \\
\hline \multicolumn{4}{|c|}{ شاخصهاى برازش تطبيقى } \\
\hline NNFI & NFI & CFI & شاخص \\
\hline$\cdot / 90$ & $\cdot / 9 F$ & $\cdot / 91$ & مقدار بهدست آمده \\
\hline 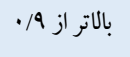 & 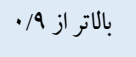 & 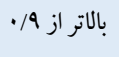 & حد قابل يذيرش \\
\hline \multicolumn{4}{|c|}{ شاخصهاى برازش تعديليافته } \\
\hline RMSEA & PNFI & $\mathrm{X}^{2} / \mathrm{df}$ & شاخص \\
\hline$\cdot 1 \cdot \Delta$ & $.19 \mathrm{~V}$ & $r / 4$ & مقدار بهدست آمده \\
\hline 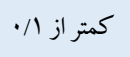 & 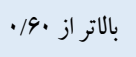 & 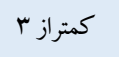 & حد قابل يذيرش \\
\hline
\end{tabular}

در جدول لا، مقادير به دسـت آمده در بثوهش حاضــر و حد قابل نتيجه گرفت كه مدل آزمون شـده، برازش مناسبى با دادههاى گردآورى

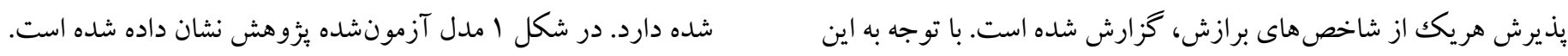

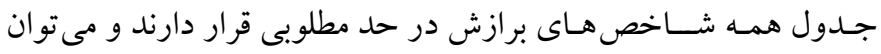

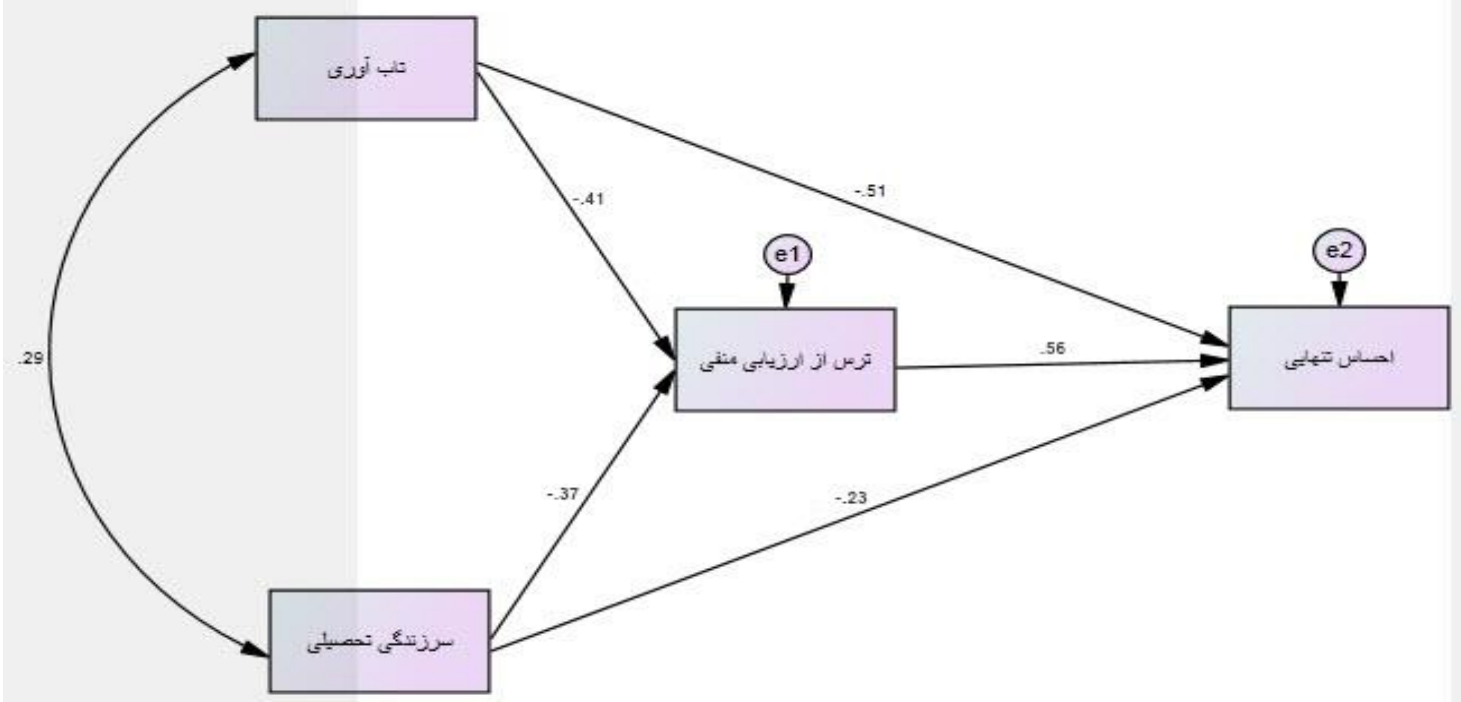

شكل ا: الكوى آزمون شده يزوهش

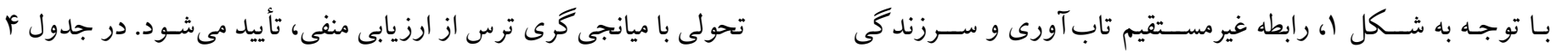

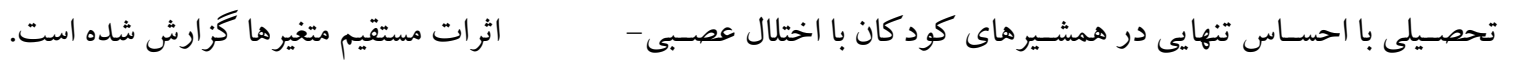


جدول ع: ضرايب و معنادارى اثرات مستقيم متغيّرهاى ثزوهش در الكو

\begin{tabular}{|c|c|c|c|c|c|c|}
\hline sig & $\mathrm{T}$ & B استانداردشده & ضريب استاندارد نشده & نوع اثر & متغير ييشبين & متغير ملاكك \\
\hline.$/ \cdot 1$ & F/A9 & $-\cdot / \Delta 1$ & $-\cdot \pi T$ & مستقيم & تاب آورى & احساس تنهايى \\
\hline.$/ .1$ & וr/r & $-\cdot / r r$ & $-\cdot \pi \Lambda$ & مستقيم & سرزندگى تحصيلى & احساس تنهايى \\
\hline.$/ .1$ & ه/N & $\cdot / \Delta 4$ & $\cdot / 94$ & مستقيم & ترس از ارزيابى منفى & احساس تنهايى \\
\hline$\% \cdot 1$ & $r / \Delta r$ & $-\cdot / 41$ & $-\cdot N a$ & مستقيم & تاب آورى & ترس از ارزيابى منفى \\
\hline.$/ .1$ & $F / 19$ & $-\cdot \mu v$ & $-\cdot / 49$ & مستقيم & سرزندگى تحصيلى & ترس از ارزيابى منفى \\
\hline
\end{tabular}

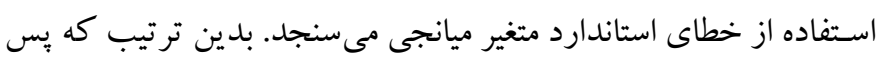

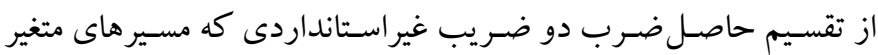

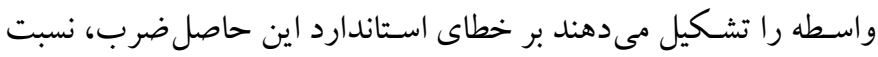

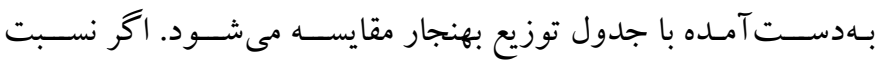

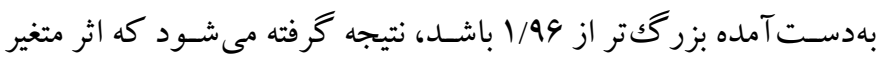

ميانجى معنادار است.
بر طبق نتايج جدول F) ضـرايب استانداردشـده مسير (اثرات مستقيم

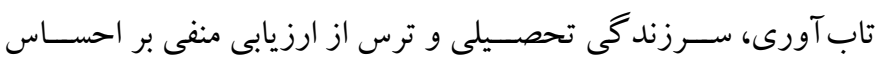

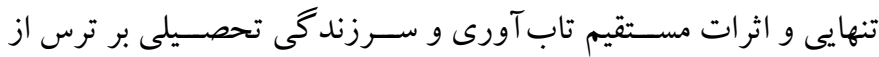

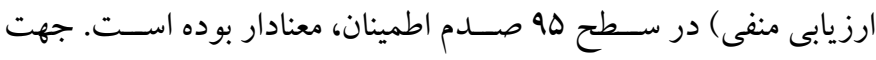
بررسى اثر متغير ميانجى ترس از ارزيابى منفى در رابطه بين تاب آورى و سـرزندگى تحصيلى با احساس تنهايى، از آزمون سوبل استفاده شد. اين ترني

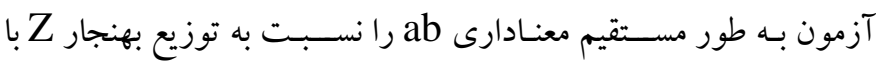

جدول 0: ضرايب و معنادارى اثرات غير مستقيم تابآورى و سرزندكى تحصيلى براحساس تنهايى

\begin{tabular}{|c|c|c|c|c|c|c|}
\hline sig & آماره سوبل & B B B B B أنداردشده & ضريب استاندارد نشده & نوع اثر & متغيّر يِيشين & متغير ملاكى \\
\hline.$/ .1$ & $r / A V$ & $-\cdot / \mu r$ & $-\cdot M$ & به واسطه ترس از ارزيابى منفى & تابآورى & احساس تنهايى \\
\hline$\cdot / \cdot r$ & r/va & $-\cdot / Y 1$ & $-\cdot / 4 \lambda$ & به واسطه ترس از ارزيابى منفى & سرزندگى تحصيلى & احساس تنهايى \\
\hline
\end{tabular}

ارتباط بين تاب آورى و سرزندگى تحصيلى با احساس تنهايى داشت.اين

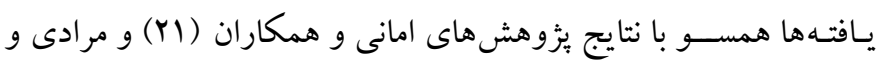

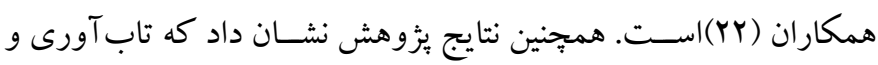

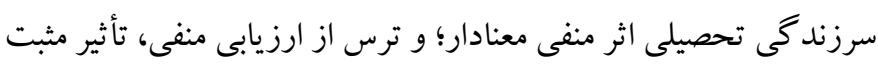

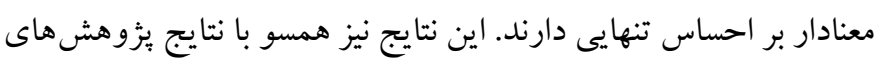

$$
\text { سودانى و همكاران (ب (Y) است. }
$$

نظريه نظام خانو اده بيان مى كند كه ارتباط اعضاى خانو اده به صورت

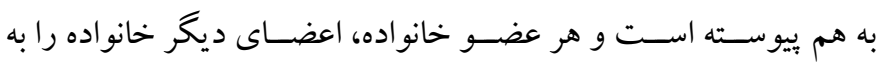
صورت مستقيم تحت تأثير قرار مىدهد. حضور يكك كود كك با نياز ويزه

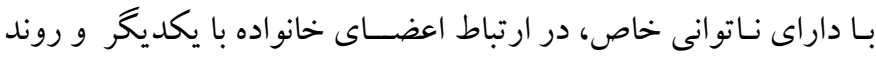

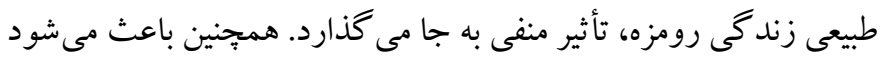

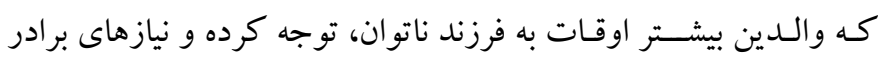

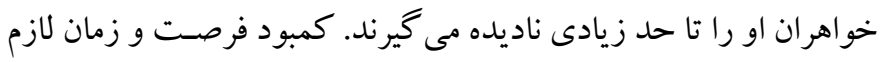
براى تفريحات مختلف اعضاى خانواده، آشفتكى در كاركرد خانو اده، و
بر اســاس نتـايج جدول ه، تاب آورى و ســرزندگى تحصــيلى اثر غيرمسـتقيم به واســـه ترس از ارزيابى منفى بر احســاس تنهايى دارند،

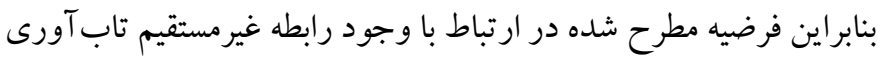

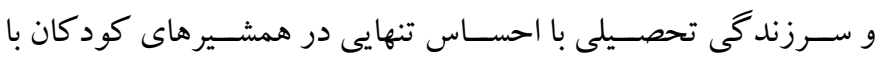

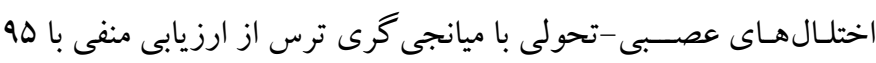
درصد اطمينان تأييد مى شود ( 10.05 (p).

\section{بحث و نتيجه كيرى} ئزوهش حاضسر با هدف بررسـى نقش ميانجى ترس از ارزيابى منفى در

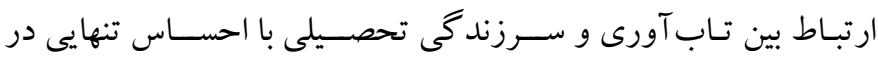

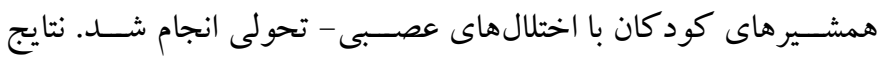

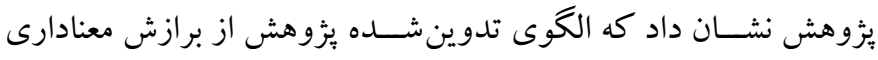
برخوردار بوده و شـاخصهاى برازش مدل به صسورت كلى در وضسعيت

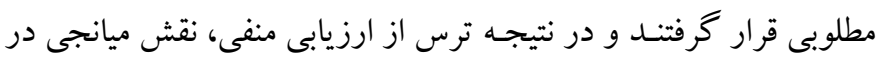


روان فرد مى شود. همجنين اين افراد ترس از ارزيابى منفى را كمتر تجربه

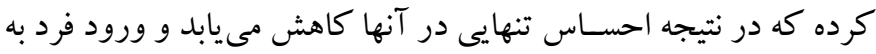

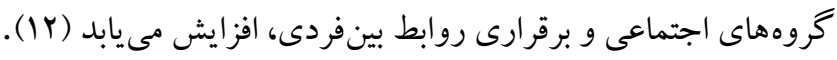
در تبيين ارتباط منفى تاب آورى با احسـاس تنهايى مى توان بيان كرد

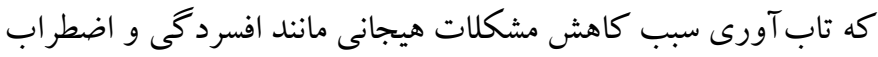

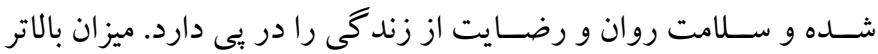

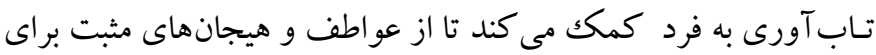

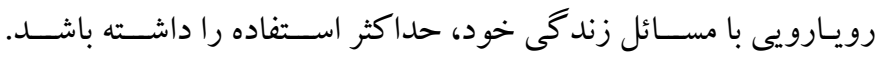

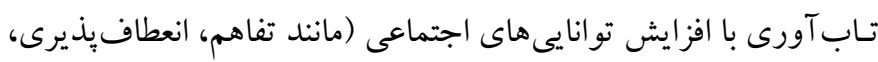
و همدلى)، افزايش مهارتهاى حل مسئله، خود كار آمديندارى، احساس هدفمندى در زندگى، و نيز برخوردارى از منبع مهار گرى درونى، موجب

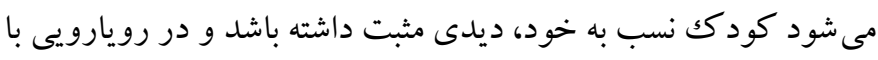

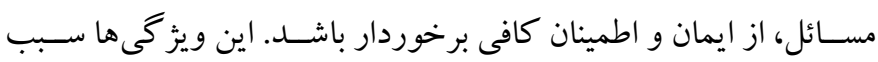

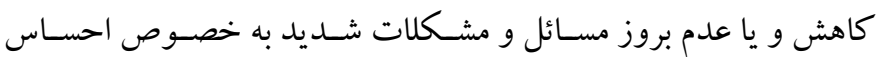
تنهايى در كود كان تاب آور مىشود (^). در يكك مطالعه (·Y)، تأثيرات منفى حضور كود كك با اختلال اوتيسم بر برادر و خواهر مورد بررسـى قرار گرفته اســت. اين تأثيرات شــامل

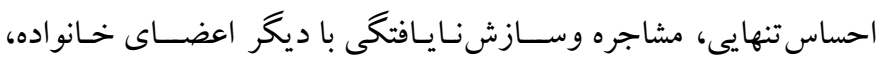

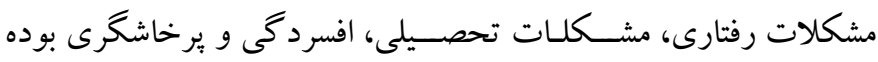

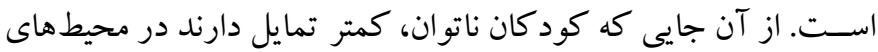

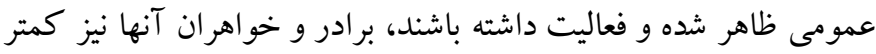

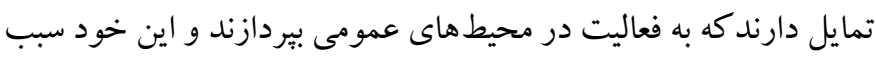

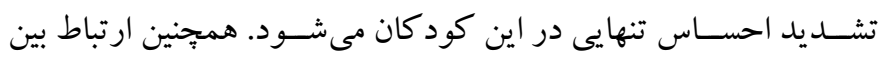

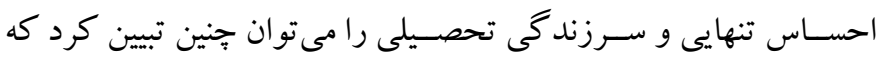

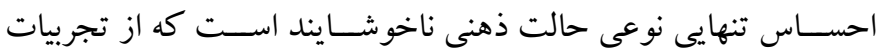

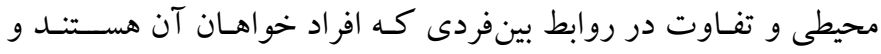

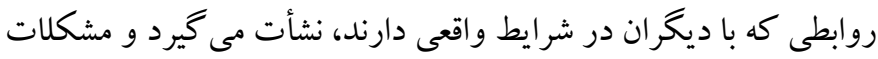

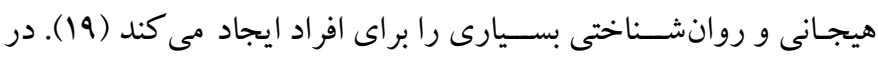

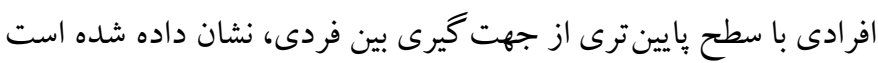

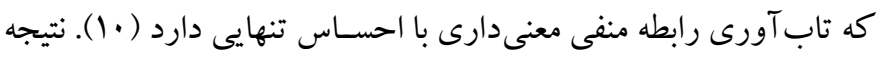
اينكه هرجه احسـاس تنهايى فرد بيشـتر باشــد، ارتباط او با همســالان در
بروز مسـائل مالى و اجتماعى از ديخر معضـاتى است كه حضور كودكى ناتوان در يكك خاتو اده ايجاد مى كند. در جنين فضـايى، كو دوكان سـالم

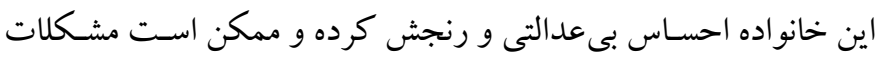

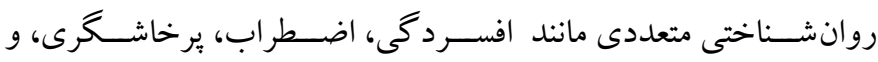
مشكلات روانتنى راب روز دهند. برادر- خواهر ان كود كان ناتوان نسبت

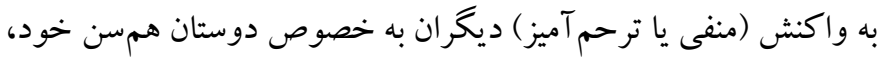

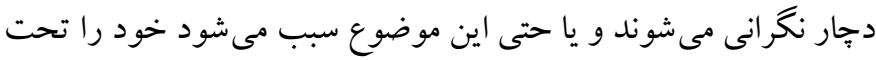

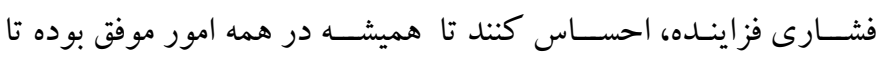

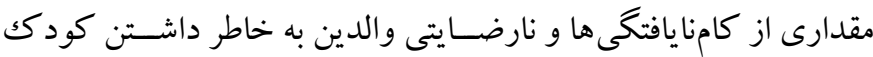

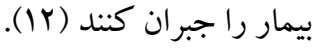
همشير هاى كود كان بيمار، احساسات و هيجانهاى خود را از والدين و جامعه ينهان مى كنند كه والدينشان در مورد آنها دجار نكخر انى نشوند و

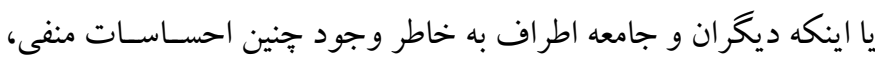

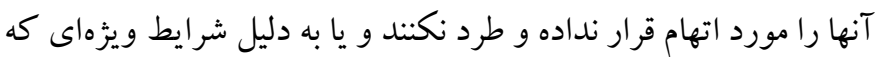

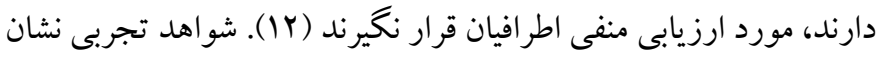
مىدهـدكه فراگيران داراى نمره بالا در تـابآورى، به دليل استفاده از اسـناد سازشافته، حتى يّ ازرويارويى با تجارب شكست، از آنجا كه كمتر در معرض آسيب ناشى از تجارب هيجانى منفى هستند، تمايل جندانى به استفاده از برخى مدلهاى منفى خودارزيابىهاى رفتارى مانند

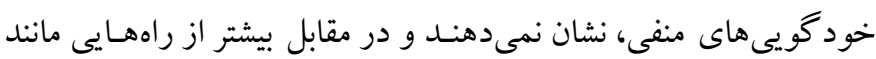

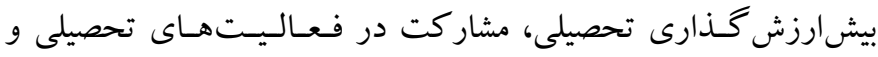
رضايتمندى از انجام تكاليف تحصيلى كه ناشى از سـرزندىى تحصيلى در آنها است، استفاده مى كنند (9). تاب آورى يكك عامل حفاظتى بويايى اســت كه به موجب آن افراد

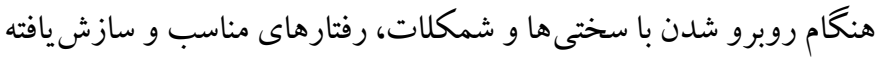
نشـان مىدهند. اين سـازه بر توانمندى، انعطاف يذيرى، توانايى تسـلط يا

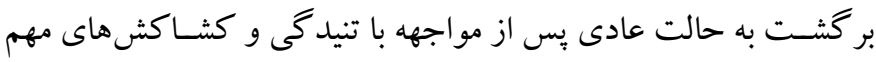

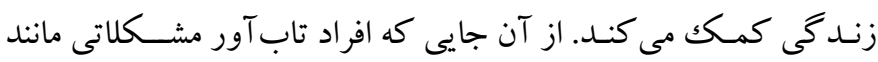

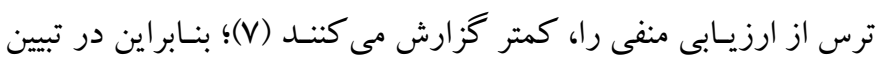
يـافتههاى اين مطالعه اين يافته مىتوان بيان كرد كه تابآورى، از طريق

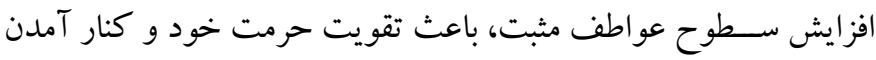

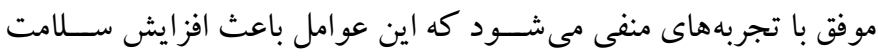


حمايت هاى اجتماعى و مالى، همخى مى توانند در مطلوبتر شـــدن و يا

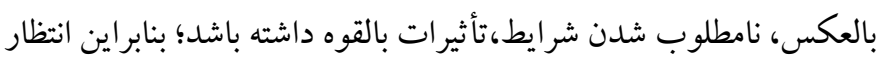

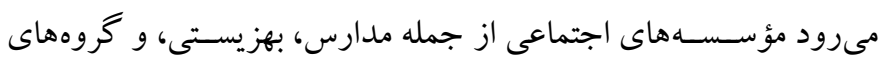

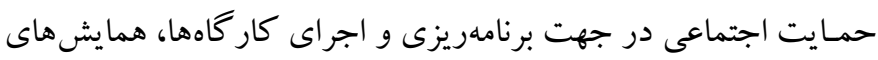

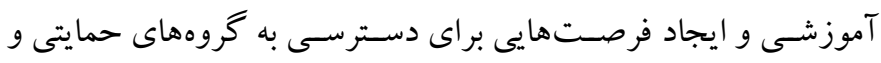

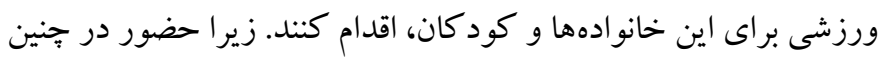
جمعيـتهـا و دريـافت حمايتهاى عاطفى و اجتماعى مى تواند از ايجاد

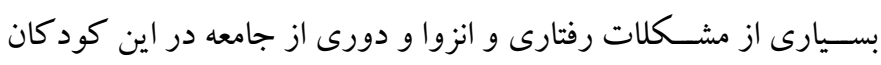

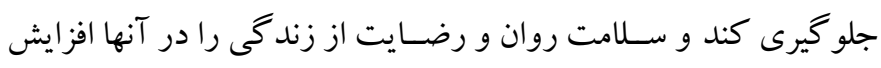
دهد. همجنين به مشـاوران و معلمان مدارس توصسيه مىشـود كه جهت شــاسـايى و مشـاوره و همدلى به برادر - خواهر ان كود كان ناتوان، اقدام

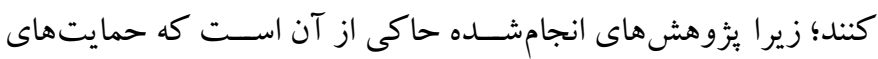

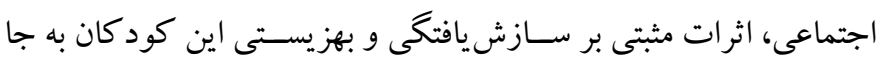
مى كذارد.

\section{ملاحظات اخلاقى}

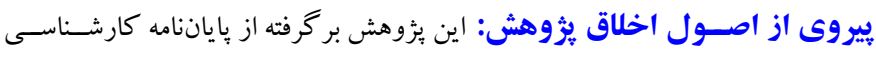

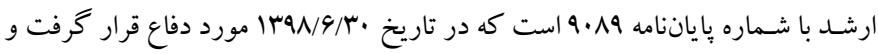

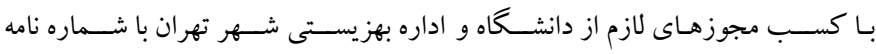

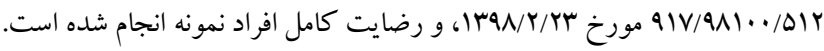

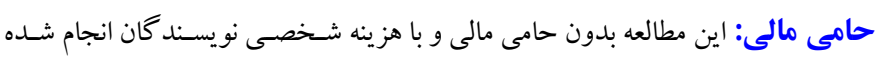

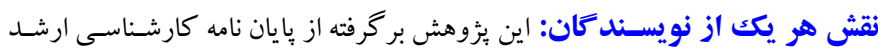

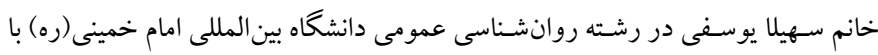

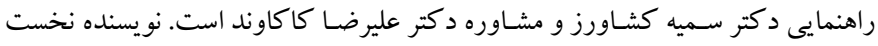

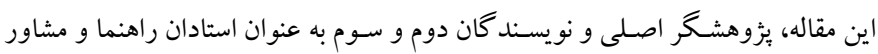

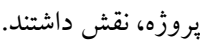

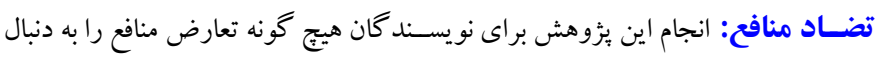

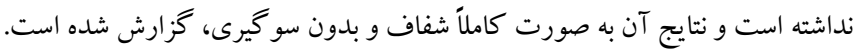

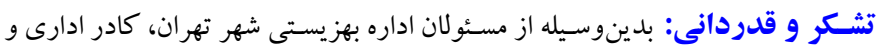

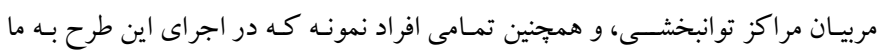
كمك كردند، تشكر و قدردانى مىشود.
محيط تحصيلى كمتر مىشود و در نتجيه شادابى و سرزندگى تحصيلى او نيز كاسته مىشود. در تبيين ارتباط مثبت ترس از ارزيابى منفى و احساس تنهايى مىتوان بيان كرد كه تنهايى به عنوان تجربهاى منفور، بر يشـان كننده و ناخوشايند

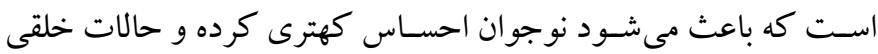

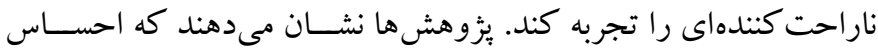
تنهايى يكك عامل سببشناختى در گروههاى سنى مختلف است و داراى

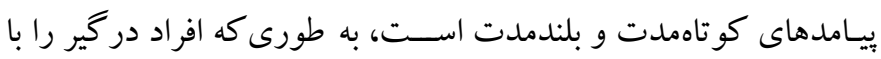

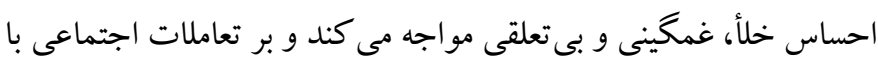

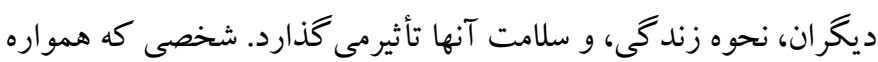

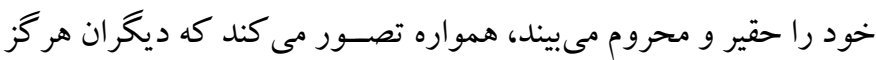

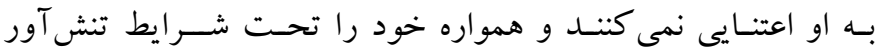

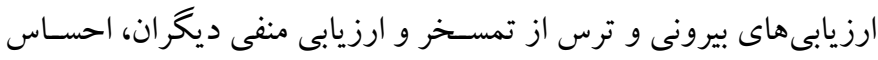

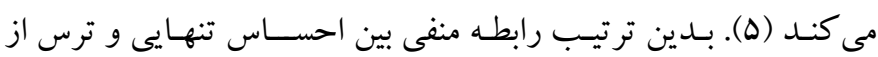
ارزيابى منفى قابل توجيه است.

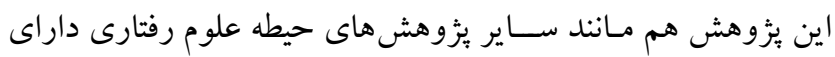

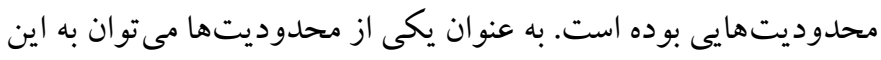

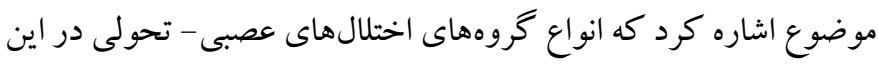

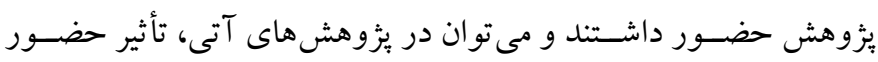

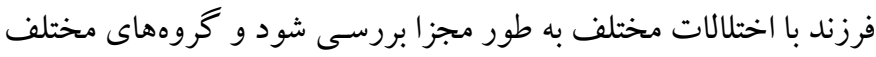

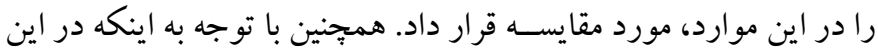

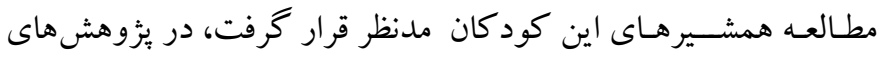

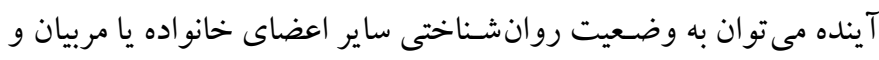

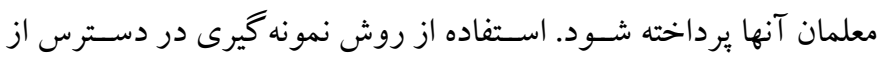

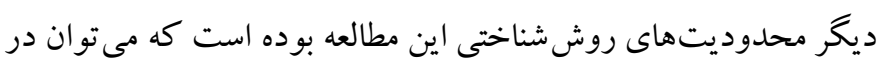
مطالعات آتى در صـورت امكان از روش نمونه گيرى تصـادفى اسـتفاده

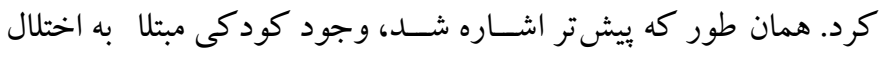

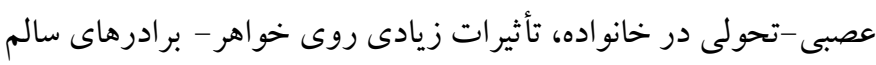

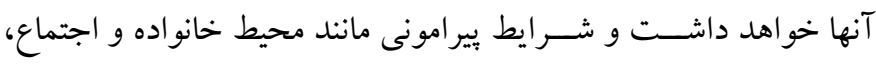
حمايت عاطفى و هيجانى والدين و دوستان، دسـترسى يذيرى امكانات و 


\section{References}

1. Pisula E. Family functioning, parenting stress and quality of life in mothers and fathers of Polish children with high functioning autism or Asperger syndrome. Journal of PLOS ONE. 2017; 12(10): 1-19. [Link]

2. American Psychatric Association. Diagnostic and Statistical Manual of Mental Disorder.Tehran: Arjmand; 2013, pp 71-120. [Persian].

3. Reichenberger J, Wiggert N, Wilhelm f.H, Liedelgruber M, Vodelhorzer U, Hillert A. Fear of negative and positive evaluation and reactivity to social-evaluative videos in social anxiety disorder. Journal of Behaviour Research and Therapy. 2019; 116 (3): 140-148. [Link]

4. Asher S.R, Wheeler V.A. Children's loneliness: A comparison of rejected and neglected peer status. Journal of Consulting and Clinical Psychology. 1985; 53(4): 500-505. [Link]

5. Cherry K. The Health Consequences of Loneliness Causes and Health Consequences of Feeling Lonely. Journal of PSYCHOTHERAPY. 2019.

6. Esfandiari $H$. The effectiveness of therapeutic attachment on love impact markers[Thesis for Master of Art]. [Sanandaj, Iran]: Faculty of Psychology, Islamic Azad University; 2013. [Persian].

7. Abdolshah A, Ghiasvand F. Economic resilience indicators. Journal of Quarterly Ravand. 2011; 22 (71): 116-73. [Persian] [Link]

8. Arnous H, Yeo K. Mediating Effect of Perceived Social Support in the Relationship Between Resilience and Self-Esteem Among Parents of Children with Autism Spectrum Disorder. Journal of Advances in Health Sciences Research. 2019; 24. [Link]

9. Shojaei S, Behpajoh A, Shokohi Yekta M, Ghobari B. Prediction of general mental health based on resilience in adolescen siblings with intellectual disabilities in Shiraz in the academic year. 2011; 2(12):21-46. [Persian]. [Link]

10. Greeff A, Nolting C. Resilience in Families of Children With Developmental Disabilities . Journal of Family System Health. 2013; 31(4): 396-405. [Link]

11. Kissel S.D, Nelson W.M. Parents' perceptions of the severity of their child's autistic behaviors and differences in parental stress, family functioning, and social support. Journal of Focus Autism Other Developemental Disability, 2016; 31(2): 152-160. [Link]

12. Fathi D, Jamalabadi M. The Study of Examined Mediating Role of Resiliency in The Perception of Academic Support and Academic
Buoyancy.EDCBMJ. 2017; 10(4): 263-269. [Persian].

13. Martin A.J, Marsh H.W. Academic buoyancy: Towards an understanding of students' everyday academic resilience. Journal of School Psychology. 2008; 46(2): 53-83. [Link]

14. Baumann S.L, Dyches T, Braddick M. Being a sibling. Nursing Science Quarterly. 2005; 18(1): 5158. [Link]

15. Van Riper M. Family variables associated with wellbeing in siblings of children with Down syndrome. Journal of Family Nursing. 2000; 6(3): 267-286. [Link]

16. Warren Dodd W. Supporting the Siblings of Young Children with Disabilities.wiley online library. 2004; 31(1):41-49. [Link]

17. Debra J, Lobato P, Barbara T. Integrated SiblingParent Group Intervention to Improve Sibling Knowledge and Adjustment to Chronic Illness and Disability. Journal of Pediatric Psychology. 2002; 27(8): 711-716. [Link]

18. Jokiranta-Olkoniemi E, Cheslack-Postava K, Joelsson P, Suominen A. Attentiondeficit/hyperactivity disorder and risk for psychiatric and neurodevelopmental disorders in siblings. Published online by Cambridge University Press. 2019; 49(1):84-91. [Link]

19. Shojaei S. Predicting the symptoms of mental health based on resilience in adolescent siblings of students with mental disabilities in shiraz during the academic year 1390-1391.quarterly journal of exceptional people. 2013; 2(6): 21-46. [Persian]. [Link]

20. Orsmond G.I, Kuo H.Y, Seltzer M.M. Siblings of individuals with an autism spectrum disorder: Sibling relationships and wellbeing in adolescence and adulthood. journal of Autism. 2009; 13(1), 59-80. [Link]

21. Amani A, Ahmadi S, Hamidi O. The Effect of Group Logotherapy on Self- Esteem and Psychological WellBeing of Female Students with Love Trauma Syndrome. journal of Pazhoheshhaye moshavere. 2013; 13(49):81-103. [Persian]. [Link]

22. Moradi M, Shahmoradi H, Mahmmodi M, Sheibani O. casual relationship of family communication pattern and religious orientation with academibuoyancy: the roles of self-efficacy dimensions. Quartery educational psychology. 2016; 12(41):91-124. [Persian]. [Link]

23. Sodani M, Shojaeeyan M, Neysi A. The effect of group logo - therapy on loneliness in retierdmen. journal of Research in cognitive and behavioral 
science. 2012; 2(1):43-54. [Persian]. [Link]

24. Lamsal R, Ungar W. Impact of growing up with a sibling with a neurodevelopmental disorder on the quality of life of an unaffected sibling: a scoping review. Journal of Disability and Rehabilitation. 2019; 1-9. [Link]

25. Segrin C. Indirect Effects of Social Skills on Health Through Stress and Loneliness. Journal of Health Communication. 2019; 34(1): 118-124. [Link]

26. Tabachnick B.G, Fidell L. S. Using multivariate statistics. Boston: Pearson Education; 1983.

27. Ungar M, Liebenberg L, Boothroyd R, Kwong W.M, Lee T.Y, Leblanc.J, et al. The study of youth resilience across cultures: Lessons from a pilot study of measurement development. Journal of Research in Human Development. 2009; 5(3), 166-180. [Link]

28. Liebenberg L,Ungar M,van de Vijver F. Validation of the Child and Youth Resilience Measure-28 (CYRM-28) among Canadian youth. Research on Social Work Practice. 2012; 22: 219-226. [Link]

29. Kazeroonizand B, Sepehri Z, Mirzaeian B. Evaluation of psychometric properties of child and adolescent resilience scale-28 in Iranian population: validity and reliability. journal of Health Breeze. 2012; 2(3):15-21. [Link]

30. Dehghani Zadeh M, Hosain Chari M. Academic vitality and perception of family communication patterns; mediating role of self-efficacy. the Journal of Studies, Teaching and Learning. 2012; 4 (2): 47-22. [Link]

31. Asher S, Hymel S, Renshaw P. Loneliness in children. journal of Child Developemental. 1984; 55: 1454-64. [Link]

32. Hosseinchari M, Khayer M. A study of the efficiency of Asher,s loneliness scale for Iranian junior high school students. Journal of social sciences and humanities of shiraz university.2003; 19(1):46-59. [Persian]. [Link]

33. Leary R.M. A brief version of the fear of negative evaluation scale. Journal of Personality and Social Psychology Bulletin. 1983; 9: 371-375. [Link]

34. Geravand f, Shokri O, Khodaei A,Omaraei M, Toulafi S. Standardization, Validity and Reliability of the Brief Fear of Negative Evaluation Scale for 12-18 Years Old Adolescents in Tehran. Journal of Psychological Studies. 2010; 7(1):65-96. [Persian]. [Link] 